Historic, Archive Document

Do not assume content reflects current scientific knowledge, policies, or practices. 



\section{There Is No Depression}

AT

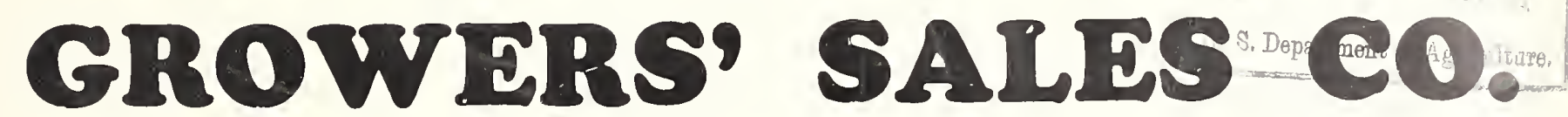

\section{T7? 9 BECAUSE You Can't Afford Not to BUY AT SUCH PRICES AS THESE}

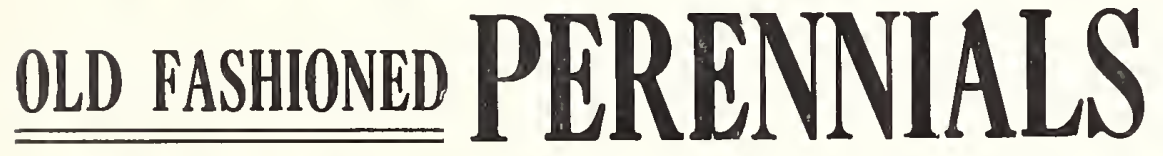

\section{"Like Grandmother Used to Have"}
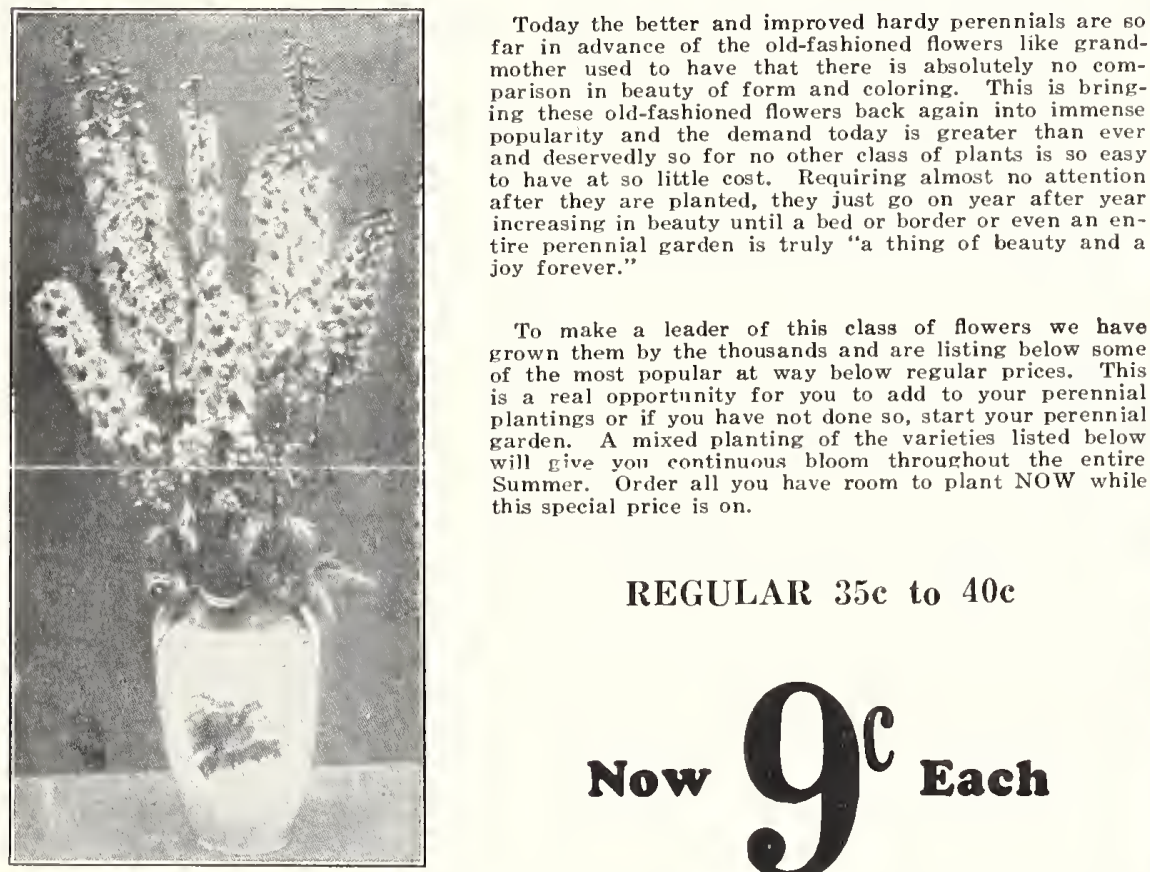

To make a leader of this class of flowers we have grown them by the thousands and are listing below some of the most popular at way below regular prices. This is a real opportunity for you to add to your perennial plantings or if you have not done so, start your perennial garden. A mixed planting of the varieties listed below garden. A mixed planting of the throties the entire Summer. Order all you have room to plant NoW while this special price is on.

REGULAR 35c to $40 \mathrm{c}$
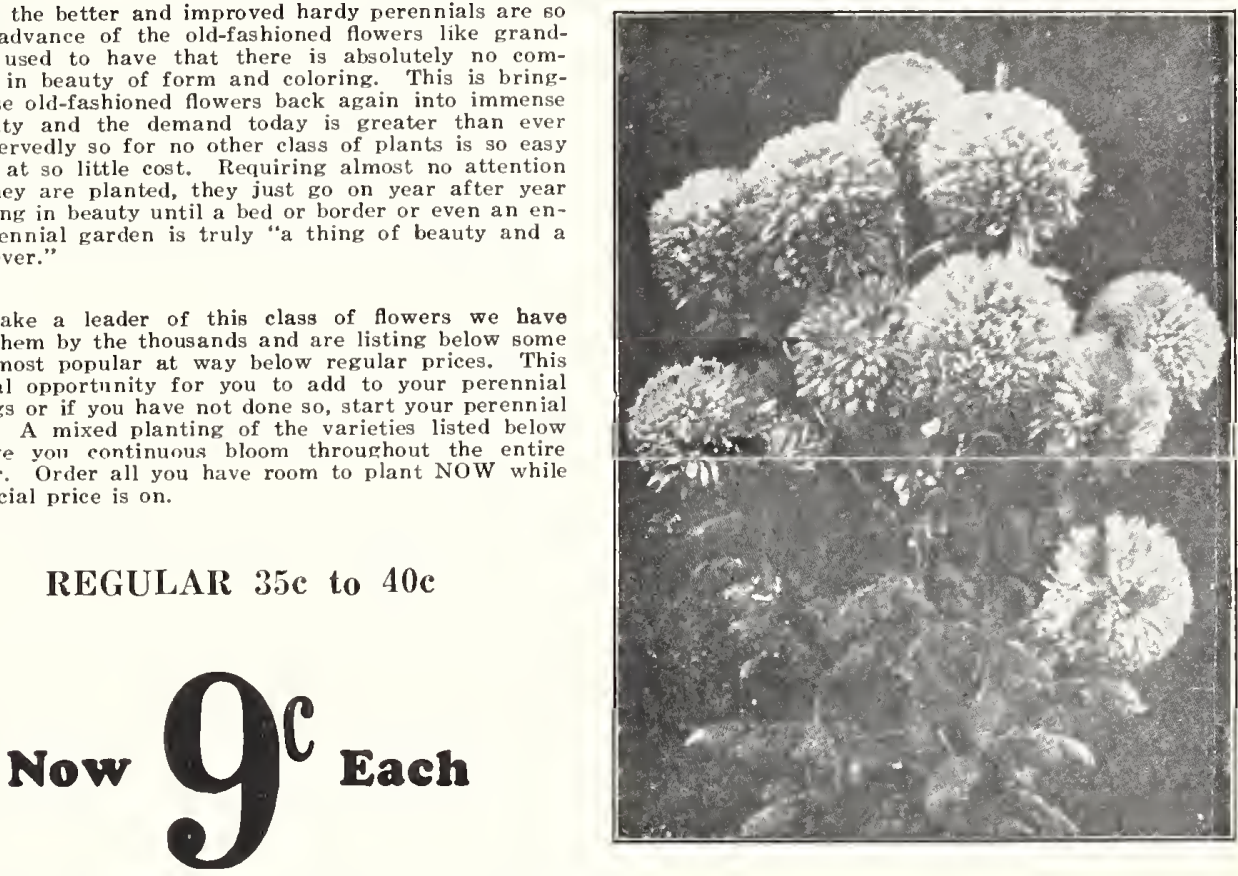

SWEET WILLIAM-One of the foremost and valuable of the perennials, producing great quantities of bloom early in the Spring.

HOLLYHOCKS_Another valuable old standby especially desirable for background planting.

HARDY GARDEN PINKS-Are in the height of their bloom in June producing in great numbers brilliantly colored flowers. They fill an important place for edging hardy borders, garden walks and in rock gardens.

ACHILLEA-The great cemetery plant. Invaluable for ceme tery planting as it commences to bloom early in July and is a perfect mass of beautiful flowers until frost.

COREOPSIS-Flowers rich golden-yellow. Bloom from June until October.

SIVET ALYSSUM-A low spreading plant valuable for rockery or border.

BABY'S BREATH-Especially valuable for mixing with other cut flowers. The blooms are semi-everlasting, keeping for months without water.

MARSHMALLOW-These large improved Marshmallow are real show plants during their flowering season.

DELPHINIUM-Has always been the favorite and most popu lar of the Perennials. It has no equal in coloring or form and is the high-light in the Perennial border or garden. Ranging in color from deepest purple blue to sky blue.

HARDY MUMS-Particularly valuable because of their late blooming season, after all other flowers have been cut down by frost, and their wide range of colors.

PIILOX-Much improved in late years, they are much larger, more abundant and more brilliant, producing a flower which is truly dazzling in its display of gorgeous colors.

\section{GROWERS'




\section{PRICE! \\ QUALITY}

\section{GARDEN IRIS}

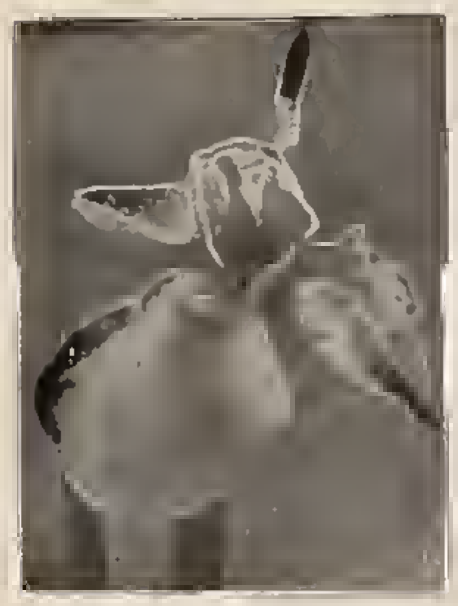

(now

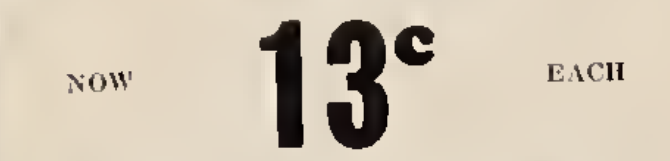

This lovely nember of the Iris Family is one of the most desirable nnd easily grown of our Spring flowering hardy plants producing in Mny their showy

most delicnte tints. The newer varieties are nuch im-

thuse newer Iris and they will quickly beconic large. massive clunps that will be a pleasure for years to markible value at this specisl low $13 \mathrm{e}$ price.

$$
\underline{10 \text { for only } \$ 1.00}
$$

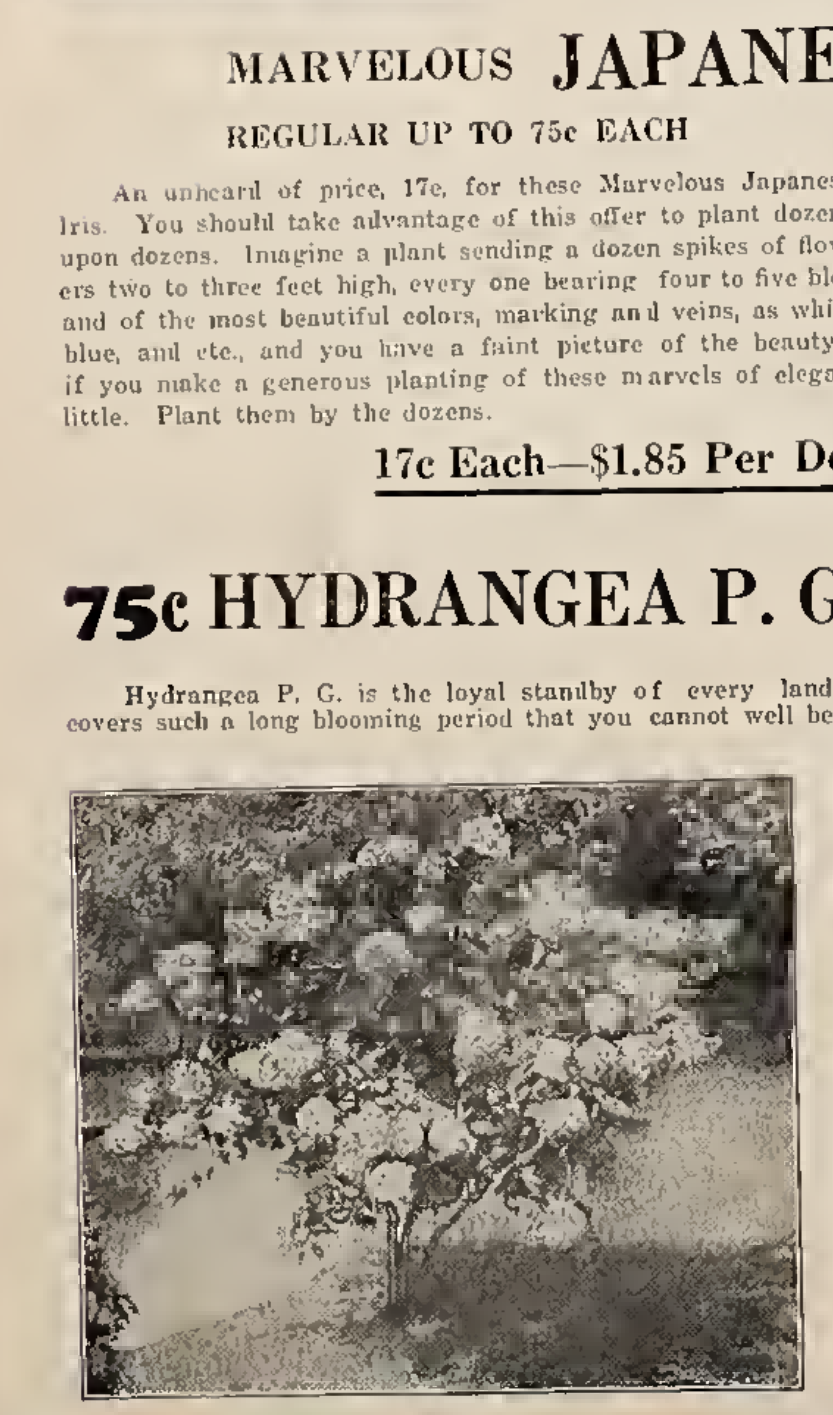
Iris. You shoull take alvantage of this after to plant dozens er's two to three feet high, every one bearing four to five blooms six to eifht inclues across, blue, anl ete., and you hive a fiaint pieture of the benuty of your garden uext sunmes $17 \mathrm{c}$ Each $-\$ 1.85$ Per Dozen

$39^{c}$ pardener. This sinut
ithout it. The large flowers
c first a nale green in July, radually turening white and
rech old-rose and lironze an be kept at any desired
height by trinuming and for
coundation planting srould

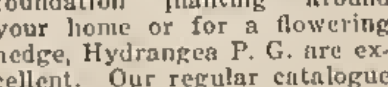
lurice for these fine twro-year
slurubs is 5 ce ench but this Fall sllubbs is $75 c$ end
you nuay have then
grcatly recluced price

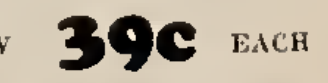

3 for Only $\$ 1.10$ 10 for $\$ 3,00$ ADD I5c TO HeLP COVER THE COST OF POSTAGE, PACKING AND INSURANCE
政

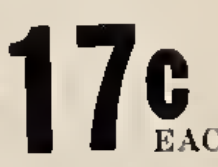

50c to 75c FLOWERING SHRUBS

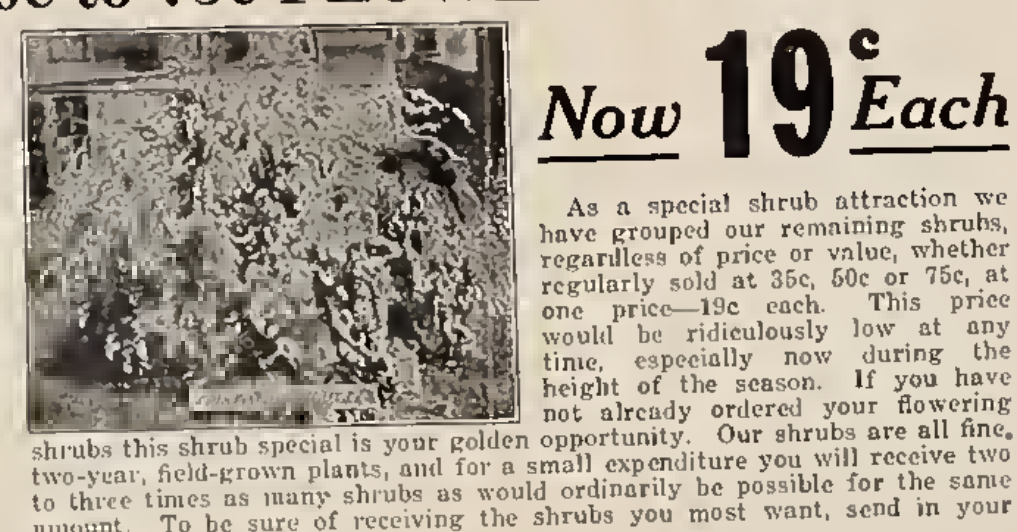

\section{torler tolay.}

AlTHAEA, Reu, Pink, Purple, White. Blooms from July to Septenber
DEWITHA, PRIIIE OF ROCHESTER. White; bloons June,

SPIRAEA YAN HOUTTEI. W'lite; blooms May,

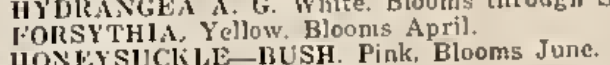

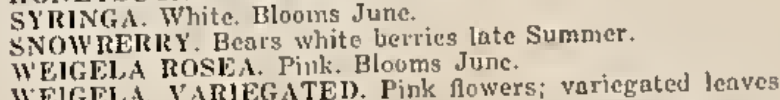

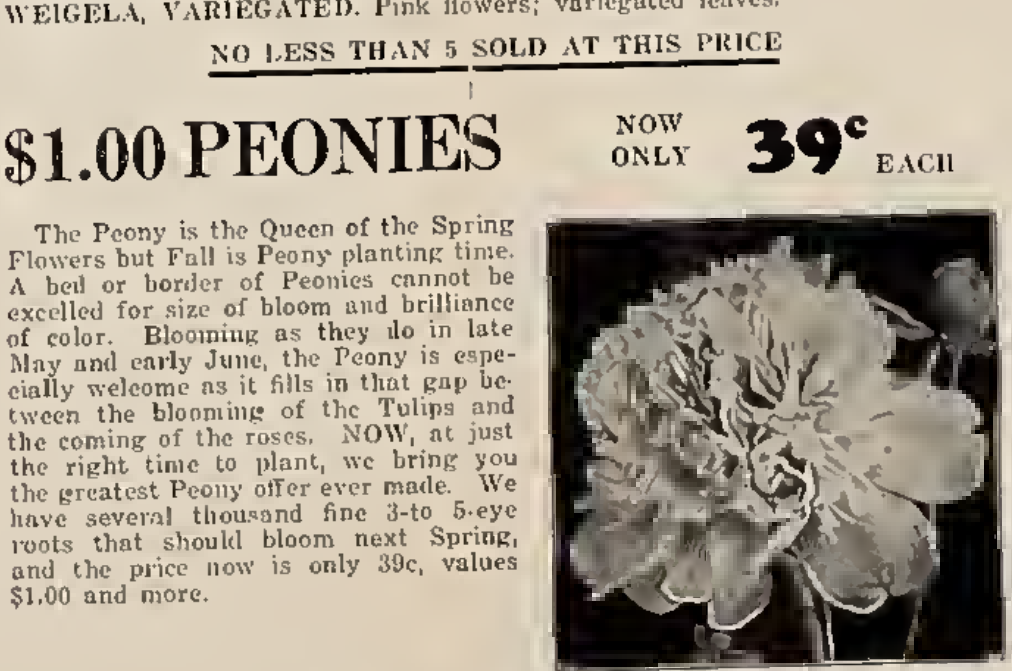

COLORS-RED, WHITE, AND PINI

39 e Each -3 For $\$ 1.10-10$ For Only $\$ 3.45$

VARIEGATED-LEAF

YUCCA

Variously catalogued at $76 \mathrm{c}$ to $\$ 1.00$ each we are able this fall to makc

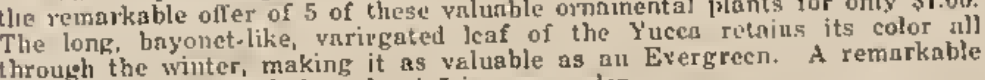

Be sure to include at leagt 5 in your orcer.

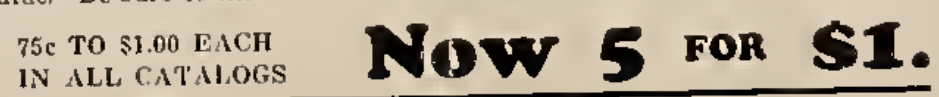

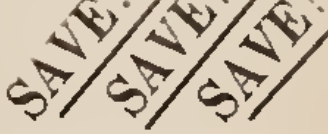

\section{BUTTERFLY BUSH}

enutiful Row-

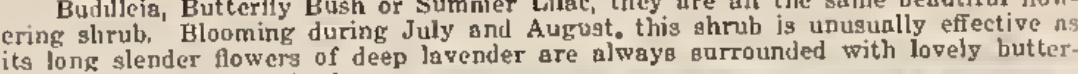

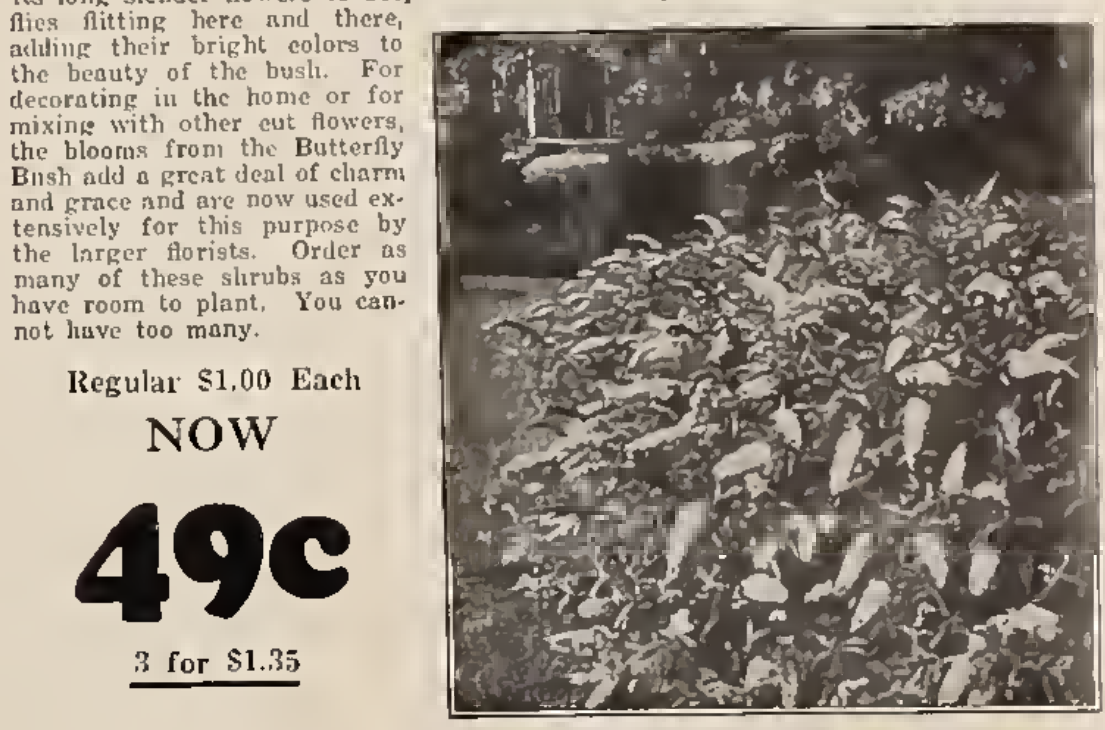

50c to 75c BOSTON IVY 27c The most valuable of all the vines for corering walls, s rbors, fences, or anywhere
ornithental k rreul coverage is desired, We wre able to make a special leater of this desirable vine this Fall at only $27 \mathrm{c}$ eacl, 5 for $\$ 1.00$, for heavily rooted plants having
top growth of about 20 inehes. A relnarkable $50 \mathrm{fe}$ to $75 \mathrm{c}$ plant at this special lurice,

$27 \mathrm{c}$ Each-5 For Only $\$ 1.00$

10 JAPANESE BARBERRY $89 \mathrm{c}$

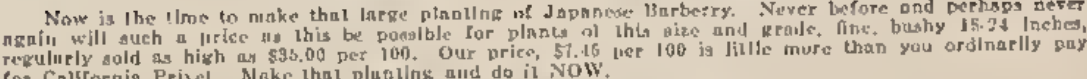
100 For Only $\$ 7.45$

\section{CALIFORNIA PRIVET}

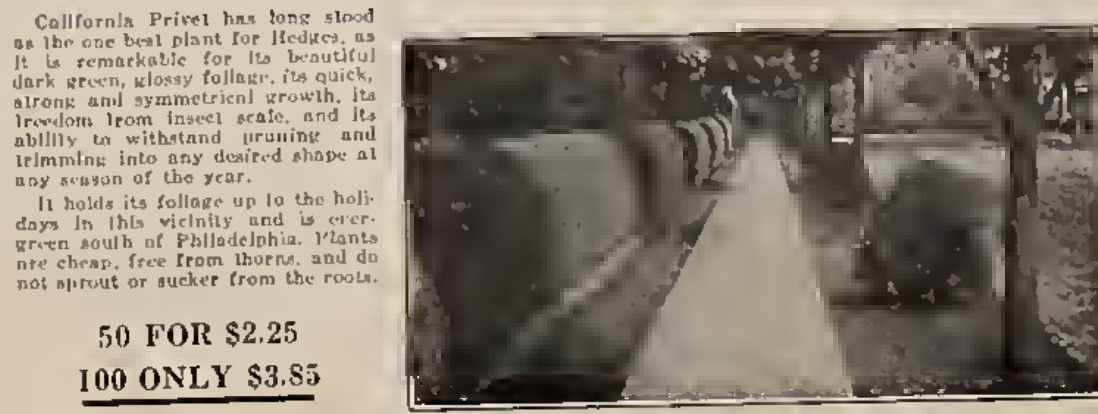




\section{Acres of Fine Fruit Trees at Less Than Half Price}

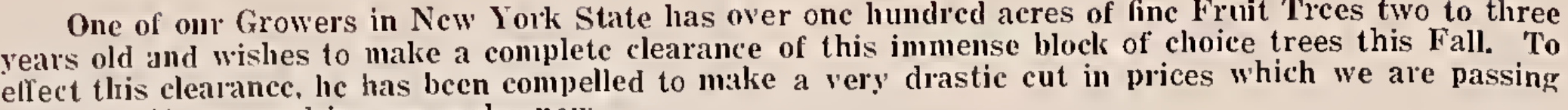

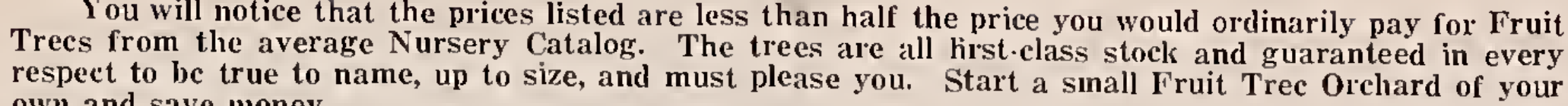
ellect this clearance, lic has becen complew.
on to you if you send in your order now.

\begin{tabular}{|c|c|}
\hline \multirow{5}{*}{$\begin{array}{l}\text { PEACH TREES } \\
\text { BELLE OF GEORGIA } \\
\text { CARMMAN } \\
\text { CHAMPION } \\
\text { ELBERTA } \\
\text { CRAWFORD'S EARLY } \\
\text { CRAWFORD'S LATE } \\
\text { 45c each-10 for } \$ 3.75\end{array}$} & PEAR TREES \\
\hline & $\begin{array}{l}\text { CLAPP'S FAVORITE } \\
\text { RARTLETT }\end{array}$ \\
\hline & $\begin{array}{l}\text { SINFFER } \\
\text { KECKEI }\end{array}$ \\
\hline & FLEMISH BEAUTY \\
\hline & $85 \mathrm{c}$ each -10 for $\$ 7.00$ \\
\hline
\end{tabular}

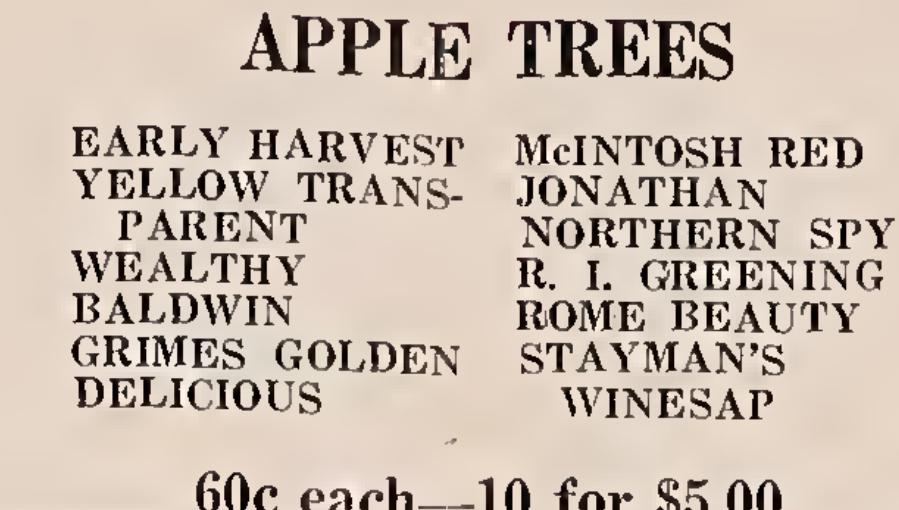

60 ceach--10 for $\$ 5.00$

\section{CHERRY TREES PLUM TREES \\ WINDSOR RTARIAN \\ NAPOLEON
NARGE MONTMORENCY
NATH \\ WRAGG \\ 90c each -10 for $\$ 7.50$}

APRICOT TREES Only 90c Each
CATALPA BUNGEII "UMBRELLA TREE"

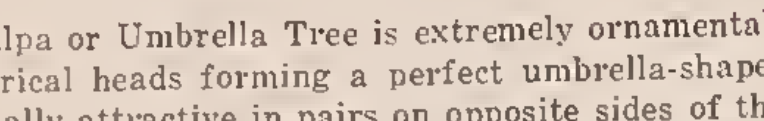

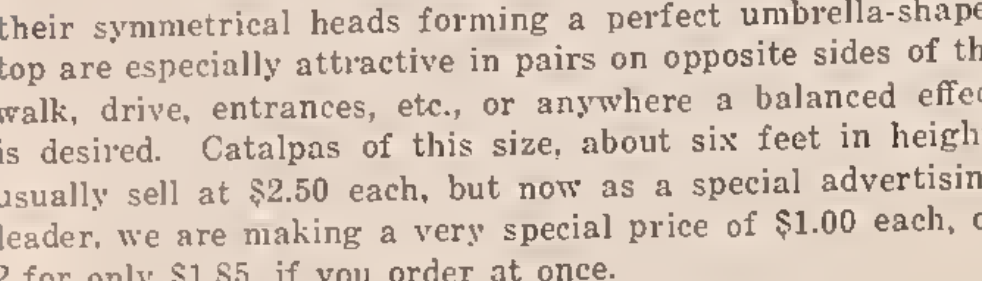

1.00 Each-2 For $\$ 1.85$

WEEPING MULBERRY

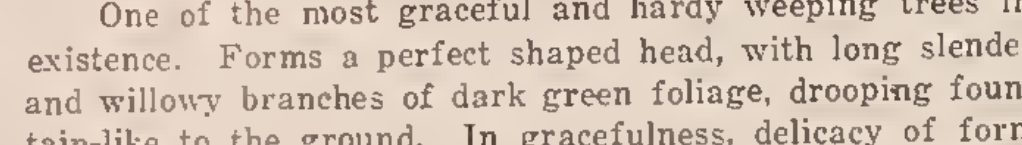

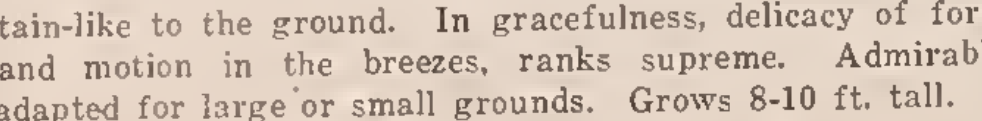

$\$ 2.50$ Each -2 For $\$ 4.75$

WEEPING WILLOW

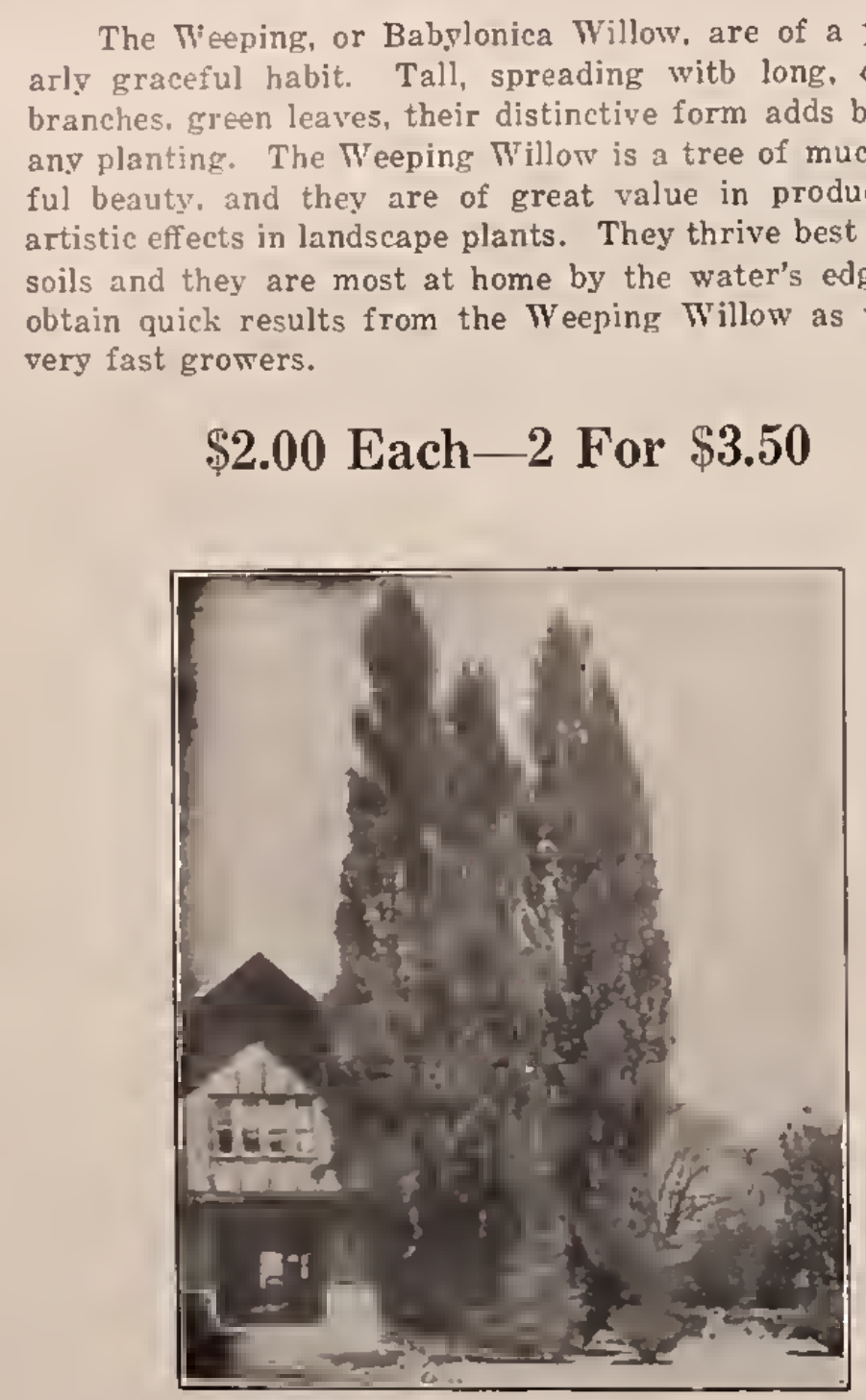

LOMBARDY POPLAR

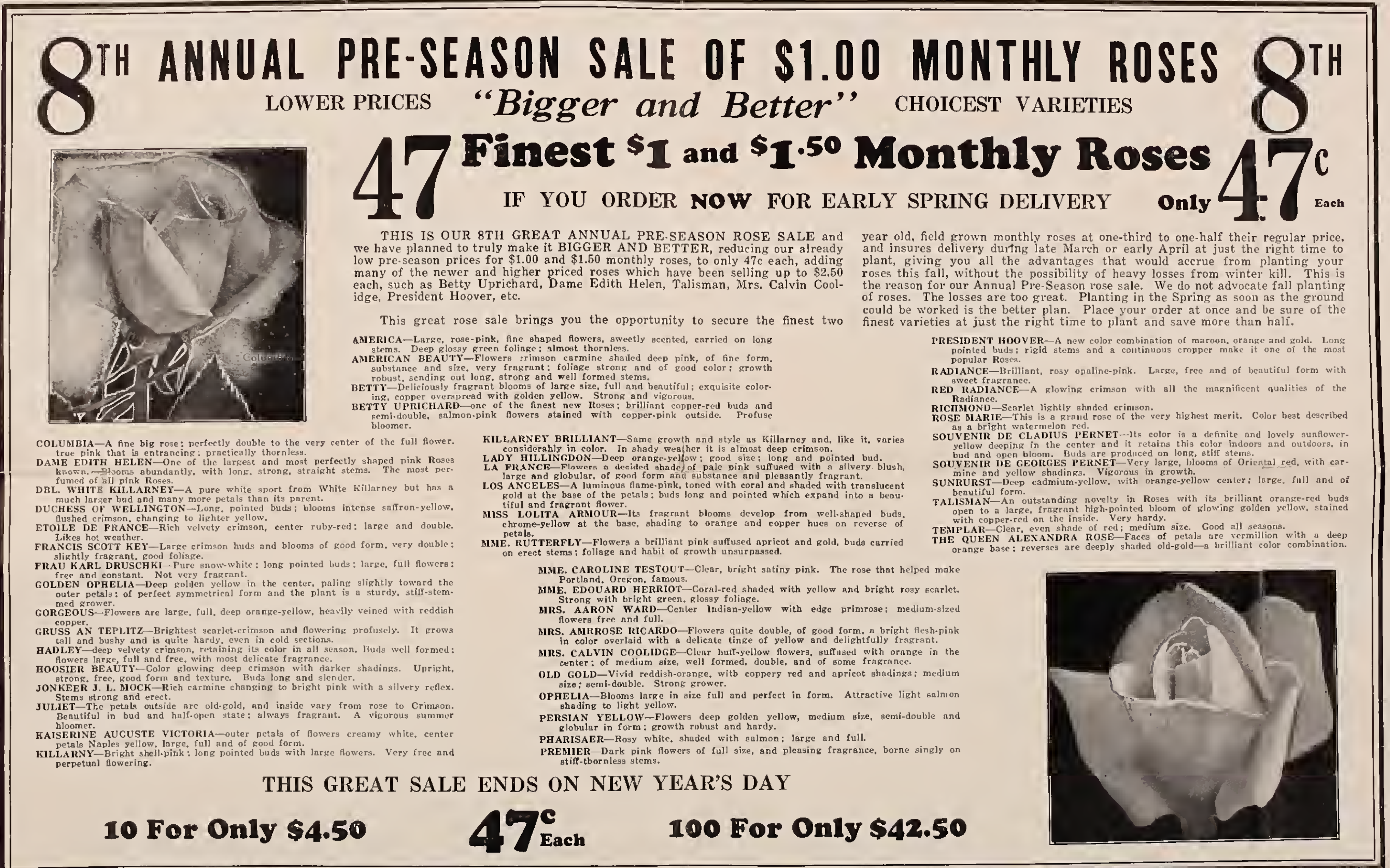

A

Growers'

Sales

Co.

Special

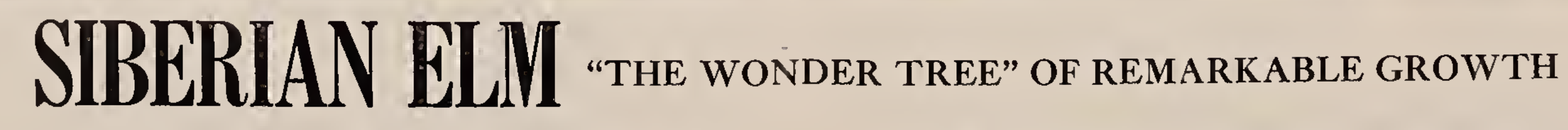

The Siberian Elm has every quality one could desire in a
shade tree beauty, quick growth, hardiness; ; thriving under con-
ditions of soil and exposure that would kill most other trees. The United States Department of Agriculture says: "It is
very hardy and has proved valuable under a greater variety of

climatic and soil conditions than any other tree yet introdnced."
The Siberian Elm is a remarkable value at our low price,

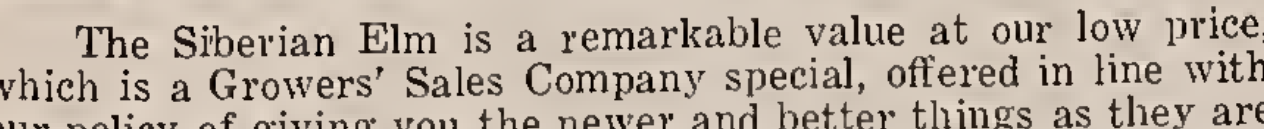
our policy of giving you the newer and better thingss as they are
proven valuable, at lower than usual prices. If you want shade,

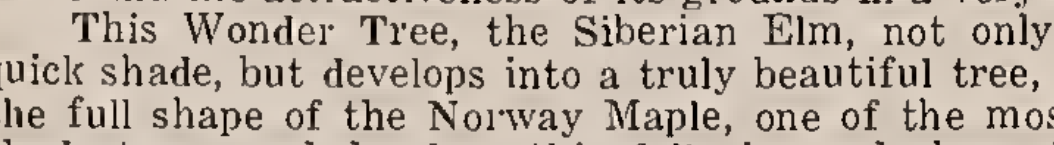

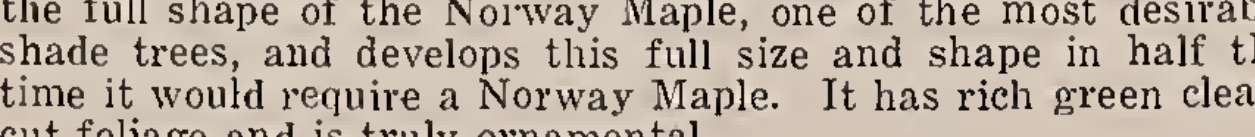

Only $\$ 1.25$ Each -3 For $\$ 3.00-10$ For Only $\$ 8.75$
Never

Sold

For Less

Than

$\$ 2.50$

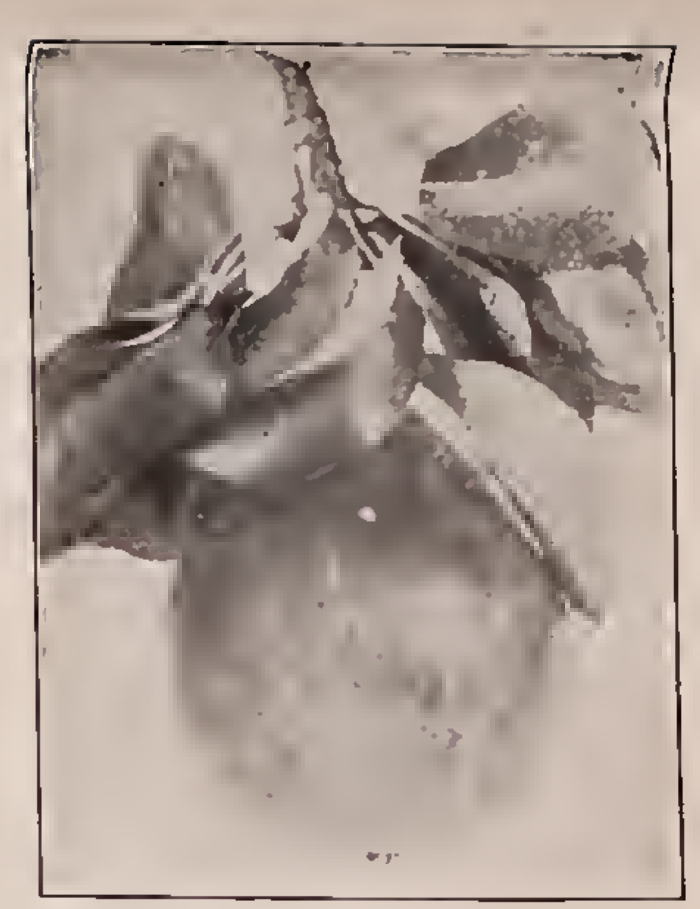

RED-LEAF TREES PRUNUS PISSARDI

\begin{tabular}{l} 
FOR \\
ONLY $\$$ \\
\hline 98
\end{tabular}

Prunus Pissardi is one of the most beautiful of the red-leaved trees, a beautiful reddish-purple, and May. Retains its color longer than any other redthree trees. Exceptionally priced.

3 for only $\$ 1.98$

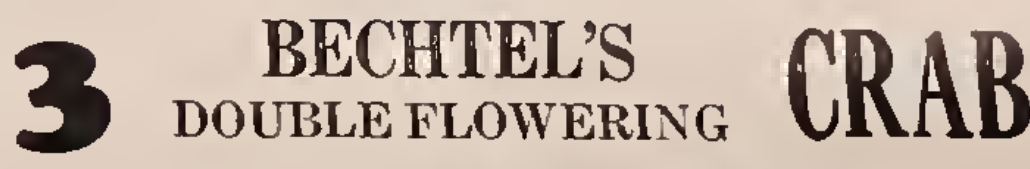
$\underset{\text { FNLY }}{\text { ONLY }} 9.98$

Most beautiful and desirable of the flowerin trees. A profusion of large, fragrant, double bloom price of one.

3 for only $\$ 1.98$

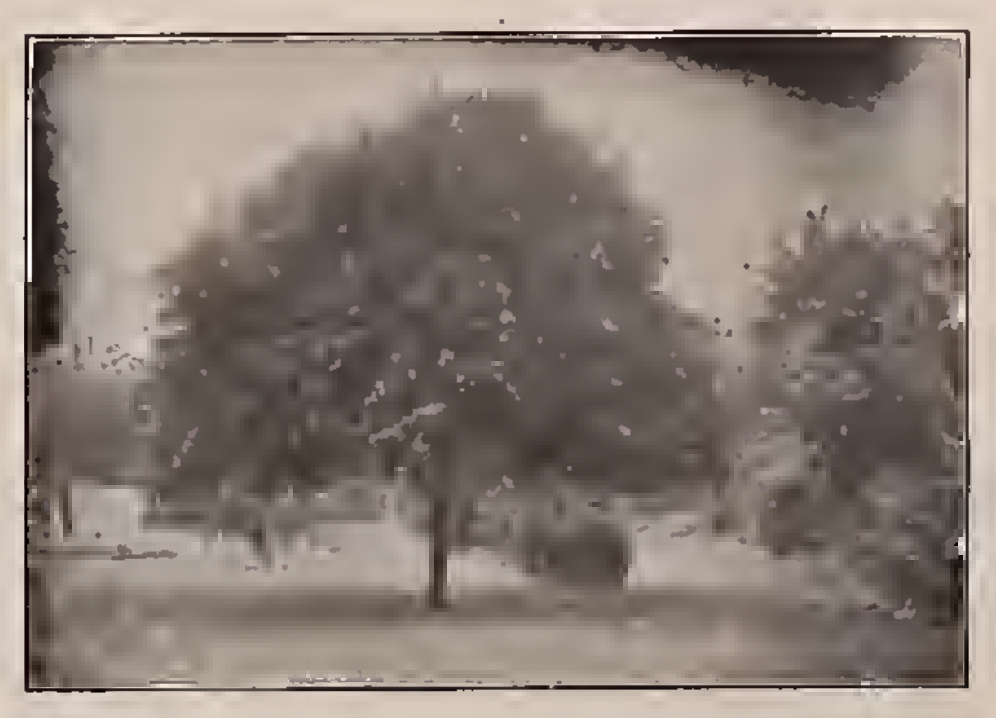

NORWAY MAPLE

Most beautiful shade tree. Perfect in form
from disease, Sturdy, compact and vigorous free from disease. Sturdy, compact and vigorous
grower, forming a rounded head of stout branches and clean, broad, deep green foliage. Perfectly hardy. Excellent for street planting or for shade on lawn. 6 to 8 foot.

$\$ 2.50$ Each -2 For $\$ 4.75$ 


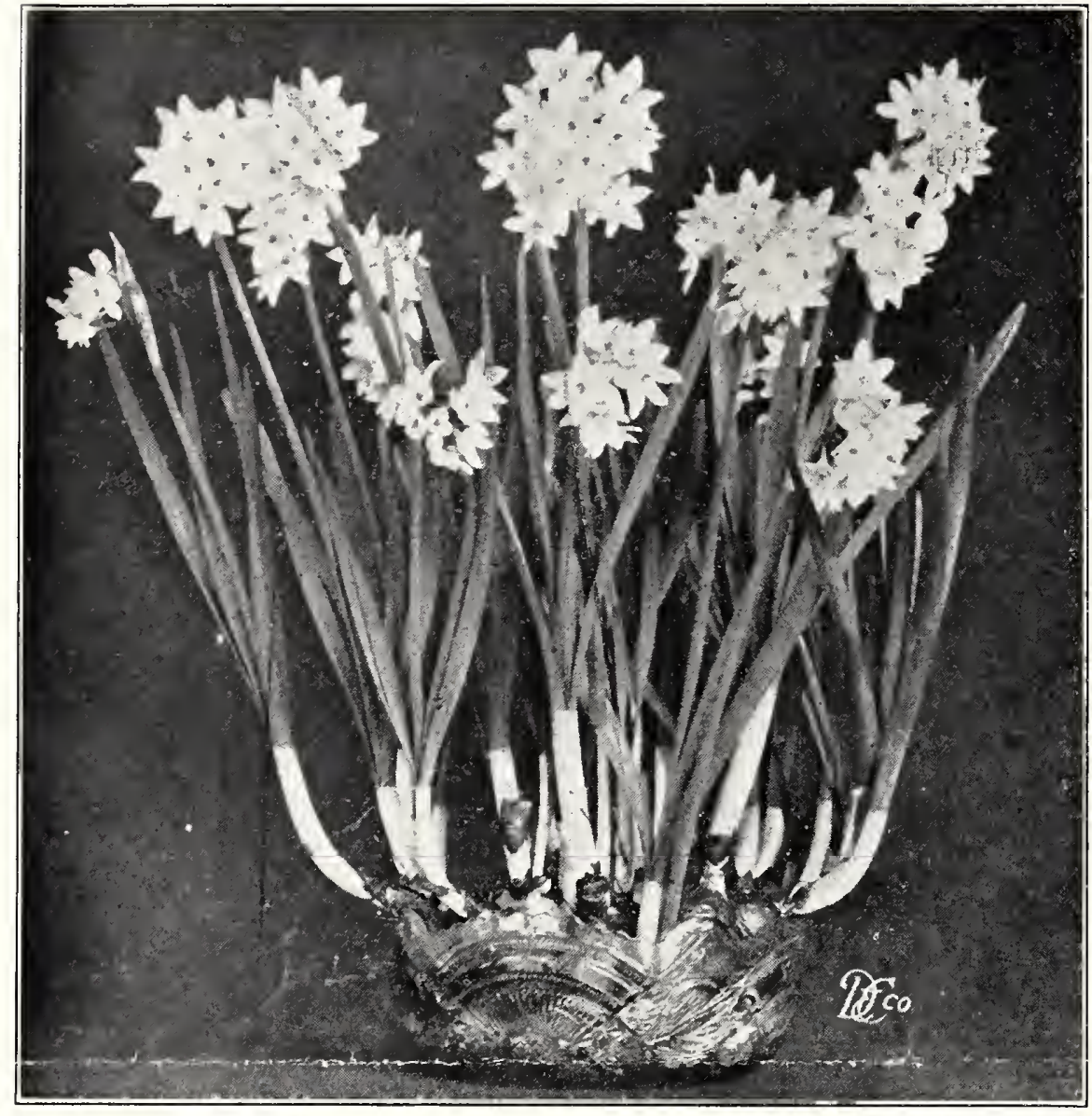

PAPERWHITE NARCISSUS

IN WATER WITH PEBBLES

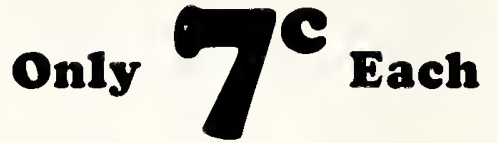

Paperwhites were one of the most popular bulbs for winter flowering indoors, until the government embargo put an end to their importation making them so scarce they were almost unobtainable last winter and so high in price as to be prohibitive to the average flower lover.

Paperwhites, of a quality that compares favorably with those formerly imported from Europe are now being grown in considerable quantities in Florida, California, and other sections of the U. S. where the soil and climate has been found favorable for their propagation. These stocks are now available but the quantity produced is, of course, very small compared to the former importations, and of necessity slightly higher in price, but by contracting early last summer for our supply we were able to secure a figure on them that enables our customers to again enjoy the beauty and fragrance of Paperwhites this winter without paying exorbitant prices.

Paperwhites grow best in water with pebbles to hold them firmly in the bowls. Keeping them well watered they will bloom for you in a few weeks time without any other care. By starting them early they can be had in flower for Christmas, and by starting them at intervals they can be kept in bloom 'til Easter. A dollar or two invested in Paperwhites will pay big dividends by filling your home with bloom all winter long.

15 for Only $\$ 1.00$

100 Only $\$ 6.00$

ADD 15c TO COVER POSTAGE, PACKING AND INSURANCE

\section{Rare, corgeous, Unusual and Fantastic U TULIPS For Only . .\$2.00}

First there are 10 brightly colored Single Tulips, 10 beautiful Double Tulips; 10 gorgeTulips, 10 ine 10 un ous Darmins; 10 ul Double Tulips: 10 gorgerful Picotee Tulips that change gradually from white to pink, almost before your eyes, 5 Parrot Tulps gorgeous in extreme in their fantastic shapes and brilliant colors; and last. but not least, 5 rare Peony Tulips that should be in every Tulip collection, 55 WONDERFUL TULIPS in all for only $\$ 2.00$.

This big SPECIAL TULIP COLLECTION will give you not only many rare and unusual varieties, but will keen your Tulip bed alive from April till after Memorial Day. In ordering, ask for the big TULIP SPECIAL.

55 Wonderful Tulips Only $\$ 2.00$

Growers' Sales Co., Clinton, N. J.
SEC. $435 \frac{1}{2}$ P. L. \& R.

U. S. POSTAGE

PAID

CLINTON, N. J.

PERMIT NO. 1 